Iranian Journal of Pathology | ISSN: 2345-3656

\title{
Epithelial-Myoepithelial Carcinoma of the Palate: Report of a Case and Review of the Literatures
}

\author{
Nazanin Mahdavi ${ }^{1}$, Maedeh Ghorbanpour ${ }^{2}$
}

1. Department of Oral and Maxillofacial Pathology, School of Dentistry, Tehran University of Medical Sciences, Tehran, Iran

2. Department of Oral and Maxillofacial Pathology, Faculty of Dentistry, Tehran Medical Sciences, Islamic Azad University, Tehran, Iran

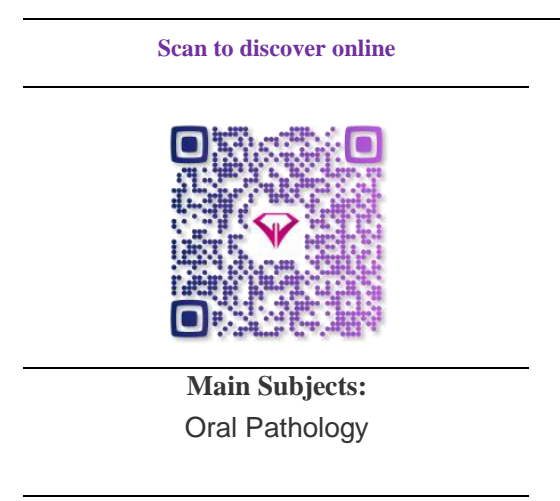

Received 11 Mar 2019;

Accepted 26 Nov 2019;

Published Online 26 Dec 2019;

$\underline{10.30699 / i j p .2020 .105039 .2076}$

\begin{abstract}
Epithelial-myoepithelial carcinoma (EMC) is considered as a rare malignant salivary gland neoplasm with good prognosis, low recurrence rate and rare metastasis. Here we present a case of epithelial-myoepithelial carcinoma in a 42-year-old female with a swelling of 3-year duration in her palate. Histopathologic evaluation of the lesion demonstrated a wellcircumscribed, biphasic salivary gland tumor composed of double-layered ductal/glandular structures, composed of small luminal eosinophilic cells and abluminal larger clear myoepithelial cells, and luminal cells were positive for pan-cytokeratin, while the abluminal cells exhibited strong immunoreactivity for p63. Ki-67 proliferative index was $1 \%$ in abluminal cells. In this article, histopathologic and immunohistochemical features of EMC and its mimics are discussed and the previously reported cases of EMC in the literature are summarized.
\end{abstract}

KEYWORDS: Clear cell tumors, Epithelial-myoepithelial carcinoma, Head and neck, Oral mucosa, Salivary gland tumor

Corresponding Information:

Maedeh Ghorbanpour, Department of Oral and Maxillofacial Pathology, Faculty of Dentistry, Tehran Medical Sciences, Islamic Azad University, Tehran, Iran Email: dr.mghb@gmail.com

Copyright ( $($ ) 2020. This is an open-access article distributed under the terms of the Creative Commons Attribution- 4.0 International License which permit Share, copy and redistribution of the material in any medium or format or adapt, remix, transform, and build upon the material for any purpose, even commercially.

\section{Introduction}

Epithelial-myoepithelial carcinoma (EMC) is considered as a rare low-intermediate grade malignant salivary gland neoplasm. This entity accounts for $1 \%$ of all salivary gland tumors (1). Most cases occur in the parotid gland, however, other sites including the minor salivary glands (specially the palate), maxillary sinus, trachea, larynx, and hypopharynx are also involved (1). This tumor has a slight female predilection and the mean age of patients at diagnosis is 60 years (2).

EMC is a low-grade malignancy (3) with good prognosis, low recurrence rate and rare metastasis (4).

This paper presents an Epithelial-myoepithelial carcinoma of the palate which the diagnosis was confirmed by immunohistochemistry.

\section{Case Report}

A 42-year-old female referred to the department of oral and maxillofacial surgery with chief complaint of swelling in her palate. The swelling was present from 3 years ago with no change in size and color of the mucosa.

The patient was non-smoker, non-drinker, and she had no history of any systemic disease or any drug history.
On clinical examination, a sessile nodule measuring $2 \times 2 \mathrm{~cm}$ was noted on left side of hard palate, area of first and second molar tooth. The overlying mucosa was intact and normal in color. The lesion was soft in consistency, and in palpation it was nontender. She stated no history of pain, paresthesia, or dysphagia. As well, there was no evidence of any lymphadenopathy on palpation.

Incisional biopsy was performed for the lesion. Grossly, the lesion revealed a spherical elastic tissue with nodular surface projections.

Microscopic examination of the specimen demonstrated a well-circumscribed neoplasm with salivary gland origin. The tumor had invaded the capsule by forming large sheets as well as small islands. The neoplasm was composed of islands, nests, and sheets of clear and eosinophilic cells that made scattered small duct-like structures lined by two layers of cells: the inner layer was composed of small cuboidal cells with eosinophilic cytoplasm, and the outer layer demonstrated large cells with clear cytoplasm. Tumor cells also revealed areas with oncocytic metaplasia in some parts and abundant deposition of hyalinized material in other areas (Figures $\underline{1 \mathrm{~A}}, \underline{\mathrm{B}}$ ).

A differential diagnosis including pleomorphic adenoma (PA), clear cell type of mucoepidermoid 
carcinoma (MEC) and epithelial myoepithelial carcinoma was suggested according to the histological findings. For the definitive diagnosis immunohistochemical (IHC) studies for ki-67, pancytokeratin and p63 was performed. The abluminal cells revealed strong immunoreactivity for p63 (Figure 2A), and luminal cells were positive for pan-

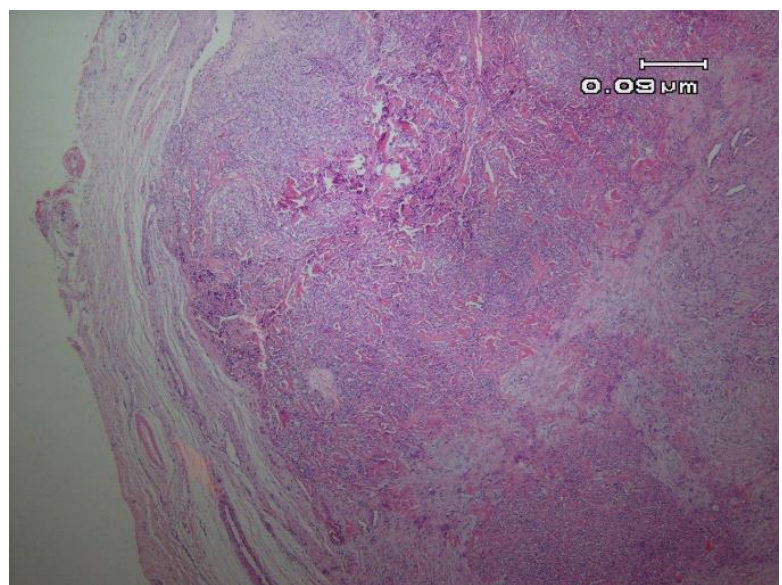

Fig. 1. A. A well-circumscribed tumor composed of a mixture of eosinophilic and clear epithelial cells (H \& E, 40X)

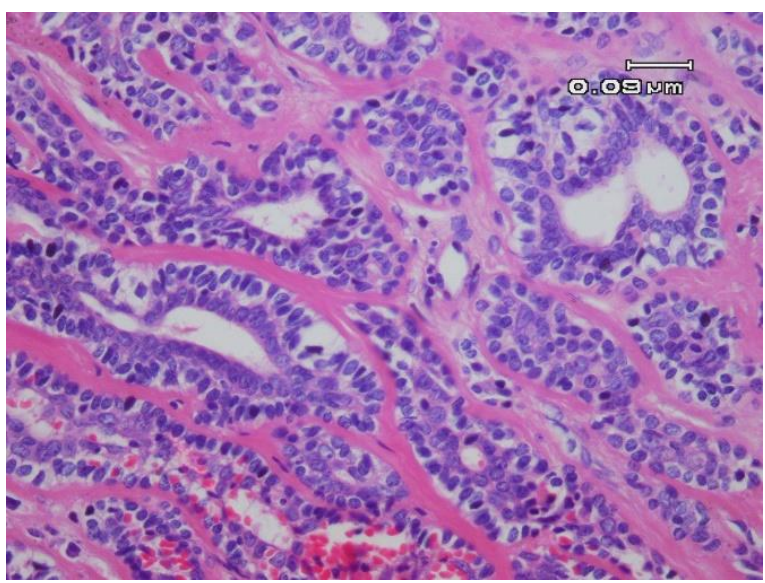

Fig. 1. B. Duct-like structures lined by one layer of epithelial cells with eosinophilic cytoplasm surrounded by a layer of clear myoepithelial cells within a hyalinized stroma (H \& E, 400X). cytokeratin (Figure 2 B). In addition, Ki-67 proliferative activity was positive in $1 \%$ of abluminal cells.

Therefore, a diagnosis of epithelial-myoepithelial carcinoma was confirmed based on the biphasic nature of the tumor.



Fig. 2. A. Positive nuclear immunohistochemical expression of p63 in the abluminal cells (IHC, 400X).

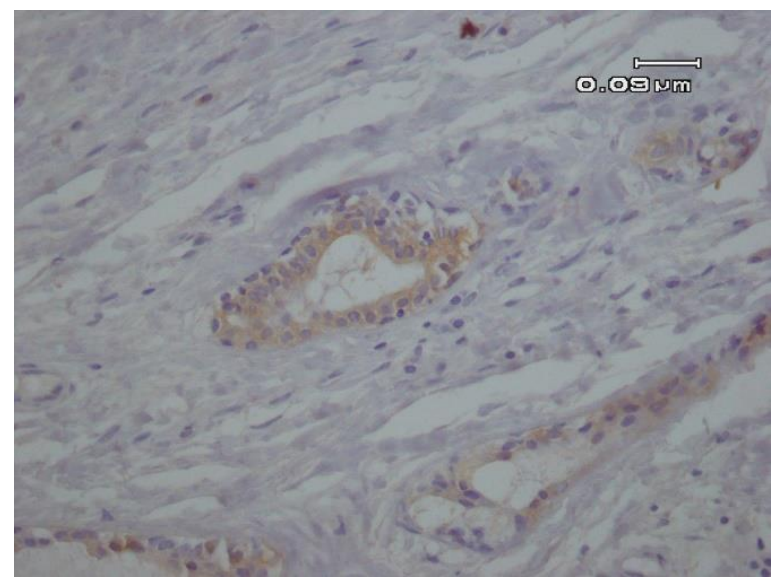

Fig. 2. B. Immunohistochemical expression of CK7 reveals cytoplasmic expression in the luminal cells (IHC, 400X).

Table 1. Previously reported cases of epithelial-myoepithelial carcinoma arising in the palate

\begin{tabular}{|c|c|c|c|c|c|c|c|}
\hline \multicolumn{2}{|c|}{ Immunohistochemistry } & \multirow[b]{2}{*}{ Histopathologic Features } & \multirow[b]{2}{*}{ Clinical Presentation } & \multirow[b]{2}{*}{ Sex } & \multirow{2}{*}{$\begin{array}{c}\text { Age } \\
\text { (years) }\end{array}$} & \multirow[b]{2}{*}{ year } & \multirow[b]{2}{*}{ Reference } \\
\hline $\begin{array}{c}\text { Positivity in } \\
\text { Myoepithelial cells }\end{array}$ & $\begin{array}{l}\text { Positivity in } \\
\text { Ductal cells }\end{array}$ & & & & & & \\
\hline $\begin{array}{c}\text { S-100 } \\
\alpha-S M A\end{array}$ & Pan keratin & $\begin{array}{l}\text { Proliferation of double-layered } \\
\text { duct-like structures with } 2 \\
\text { distinctive cell types. The } \\
\text { inner layer of eosinophilic } \\
\text { epithelial cells, and outer } \\
\text { layer of clear cells }\end{array}$ & $\begin{array}{l}\text { Swelling since } 20 \text { years } \\
\text { ago }\end{array}$ & M & 72 & 1996 & $\begin{array}{c}\text { Kusama et } \\
\text { al (7) }\end{array}$ \\
\hline GFAP & CK & $\begin{array}{l}\text { Multiple tubular or solid nests } \\
\text { separated by a basement } \\
\text { membrane and consisted of } \\
\text { variable proportions of } 2 \text { cell } \\
\text { types, cuboidal epithelial and } \\
\text { clear myoepithelial cells }\end{array}$ & - & $\mathrm{F}$ & 72 & 2000 & Li et al (8) \\
\hline
\end{tabular}




\begin{tabular}{|c|c|c|c|c|c|c|c|}
\hline \multicolumn{2}{|c|}{ Immunohistochemistry } & \multirow[b]{2}{*}{ Histopathologic Features } & \multirow[b]{2}{*}{ Clinical Presentation } & \multirow[b]{2}{*}{ Sex } & \multirow{2}{*}{$\begin{array}{c}\text { Age } \\
\text { (years) }\end{array}$} & \multirow[b]{2}{*}{ year } & \multirow[b]{2}{*}{ Reference } \\
\hline $\begin{array}{c}\text { Positivity in } \\
\text { Myoepithelial cells }\end{array}$ & $\begin{array}{l}\text { Positivity in } \\
\text { Ductal cells }\end{array}$ & & & & & & \\
\hline S-100 & CK & $\begin{array}{l}\text { Round to oval cells with } \\
\text { moderate amount of pale pink } \\
\text { to clear cytoplasm and round } \\
\text { to oval eccentrically placed } \\
\text { mildly pleomorphic vesicular } \\
\text { nuclei with small prominent } \\
\text { nucleoli, occasional mitotic } \\
\text { figure, some nodules showed } \\
\text { central necrosis }\end{array}$ & $\begin{array}{l}\text { Nodular swelling with } \\
\text { surface ulceration on } \\
\text { hard palate, no history of } \\
\text { pain, no evidence of } \\
\text { cervical } \\
\text { lymphadenopathy }\end{array}$ & $\mathrm{F}$ & 36 & 2008 & Pai et al (9) \\
\hline $\begin{array}{c}\text { P63 } \\
\text { calponin } \\
\text { S100 }\end{array}$ & $\begin{array}{c}\text { CK AE-1/AE-3 } \\
\text { EMA } \\
\text { CK5/6 }\end{array}$ & \multirow{2}{*}{$\begin{array}{l}2 \text { cell types, an inner layer of } \\
\text { cuboidal eosinophilic duct-like } \\
\text { cells \& an outer layer of } \\
\text { polygonal myoepithelial } \\
\text { cells with hyalinized stroma }\end{array}$} & $\begin{array}{c}\text { A painless \& } \\
\text { asymptomatic mass with } \\
\text { intact mucosa on hard } \\
\text { palate }\end{array}$ & M & 83 & 2009 & $\begin{array}{l}\text { Angiero et } \\
\text { al (10) }\end{array}$ \\
\hline $\begin{array}{c}\text { p63 } \\
\text { calponin } \\
\text { S100 } \\
\text { SMA }\end{array}$ & $\begin{array}{c}\text { CK AE-1/AE-3 } \\
\text { CK7 } \\
\text { EMA } \\
\text { CK5/6 }\end{array}$ & & $\begin{array}{l}\text { A mass in palate \& } \\
\text { history of intermittent } \\
\text { pain, no cervical } \\
\text { lymphadenopathy }\end{array}$ & $\mathrm{F}$ & 58 & 2009 & $\begin{array}{l}\text { Angiero et } \\
\text { al (10) }\end{array}$ \\
\hline$\alpha$-SMA & $\begin{array}{l}\text { CK7 } \\
\text { CK14 }\end{array}$ & $\begin{array}{l}\text { Double-layered duct-like } \\
\text { structures with an inner layer } \\
\text { of small cuboidal to oval } \\
\text { epithelial cells with a central } \\
\text { hyperchromatic nucleus and } \\
\text { outer layer of polygonal with } \\
\text { more abundant, clear, } \\
\text { vacuolated and well-defined } \\
\text { cytoplasm myoepithelial cells }\end{array}$ & $\begin{array}{l}\text { A growing mass with } \\
\text { regular surface } \& \\
\text { erythematous } \\
\text { from } 1 \text { year ago on soft } \\
\text { palate, difficulty in } \\
\text { breath }\end{array}$ & $\mathrm{F}$ & 76 & 2010 & $\begin{array}{c}\text { Muniz } \\
\text { Alves et al } \\
\text { (11) }\end{array}$ \\
\hline $\begin{array}{c}\alpha-S M A \\
\text { Calponin } \\
\text { p63 }\end{array}$ & CK7 & $\begin{array}{c}\text { Duct-like structures with } \\
\text { luminal and clear abluminal } \\
\text { cells, minimal nuclear atypia, } \\
\text { no perineural/ angiolymphatic } \\
\text { invasion }\end{array}$ & $\begin{array}{c}\text { A mass on soft palate, } \\
\text { speech problems, } \\
\text { dysphagia from } 2 \text { months } \\
\text { ago }\end{array}$ & $\mathrm{F}$ & 66 & 2015 & $\begin{array}{l}\text { Dimitrijevic } \\
\text { et al (6) }\end{array}$ \\
\hline \multirow[t]{2}{*}{$\begin{array}{c}\text { CK14 } \\
\text { Vimentin } \\
\text { p63 } \\
\alpha \text {-SMA }\end{array}$} & \multirow[t]{2}{*}{$\begin{array}{c}\text { Pan- CK } \\
\text { CK7 } \\
\text { focally CK14 }\end{array}$} & $\begin{array}{l}\text { Eosinophilic duct-forming } \\
\text { cells which are polygonal in } \\
\text { shape with } \\
\text { eosinophilic cytoplasm } \\
\text { surrounded by clear cells, } \\
\text { moderate nuclear atypia, no } \\
\text { perineural/ angiolymphatic } \\
\text { invasion }\end{array}$ & $\begin{array}{l}\text { As a component of ca- } \\
\text { ex-pa }\end{array}$ & M & 42 & 2015 & $\begin{array}{l}\text { Sedassari et } \\
\text { al (2) }\end{array}$ \\
\hline & & $\begin{array}{l}\text { Same as above features except } \\
\text { for mild nuclear atypia }\end{array}$ & $\begin{array}{l}\text { As a component of ca- } \\
\text { ex-pa }\end{array}$ & $\mathrm{F}$ & 56 & 2015 & $\begin{array}{l}\text { Sedassari et } \\
\text { al (2) }\end{array}$ \\
\hline $\begin{array}{c}\text { S-100 } \\
\alpha-S M A\end{array}$ & CKs & $\begin{array}{l}\text { Biphasic structure consisting } \\
\text { of duct-lining cuboidal cells in } \\
\text { the inner layer and clear } \\
\text { myoepithelial cells in the outer } \\
\text { layer }\end{array}$ & $\begin{array}{l}\text { Painless swelling of } 2 \\
\text { months duration }\end{array}$ & M & 40 & 2016 & $\begin{array}{l}\text { Pereira et al } \\
\quad(12)\end{array}$ \\
\hline P63 & Pan- CK & $\begin{array}{c}\text { A well-circumscribed, } \\
\text { biphasic salivary gland tumor } \\
\text { composed of double-layered } \\
\text { ductal/glandular structures, } \\
\text { composed of small luminal } \\
\text { eosinophilc cells and } \\
\text { abluminal larger clear } \\
\text { myoepithelial cells }\end{array}$ & $\begin{array}{l}\text { A sessile nodule on left } \\
\text { side of hard palate with } \\
\text { no history of pain, } \\
\text { paresthesia, or dysphagia }\end{array}$ & $\mathrm{F}$ & 42 & 2019 & $\begin{array}{l}\text { The present } \\
\text { case }\end{array}$ \\
\hline
\end{tabular}

M: male, F: female, Ca-Ex-PA: carcinoma-ex-pleomorphic adenoma, CK: cytokeratins, $\alpha$-SMA: $\alpha$-smooth muscle actin, EMA: epithelial membrane antigen, GFAP: glial fibrillary acidic

Table 2. Differential immunohistochemistry in epithelial-myoepithelial carcinoma and the mimics

$\begin{array}{cccccccccccccccccc}\text { Diagnosis } & \text { CK } & \text { EMA } & \text { CEA } & \text { CAM5.2 } & \text { p63 } & \text { Calponin } & \begin{array}{c}\text { H- } \\ \text { caldesmon }\end{array} & \begin{array}{c}\alpha- \\ \text { SMA }\end{array} & \text { MSA } & \text { SMM } & \text { S100 } & \text { Vimentin } & \text { GFAP } & \begin{array}{c}\text { c- } \\ \text { KIT }\end{array} & \text { PLAG1 } & \text { RCC/CD10 } \\ \text { PA } & + & + & + & \text { N/A } & + & + & \text { N/A } & + & + & + & + & + & + & +/- & + & - \\ \text { AdCC } & + & + & + & \text { N/A } & + & + & \text { N/A } & + & \text { N/A } & + & + & \text { N/A } & - & + & - & -\end{array}$




$\begin{array}{rlllllllllllllllll}\text { Diagnosis } & \text { CK } & \text { EMA } & \text { CEA } & \text { CAM5.2 } & \text { p63 } & \text { Calponin } & \begin{array}{c}\text { H- } \\ \text { caldesmon }\end{array} & \begin{array}{c}\alpha- \\ \text { SMA }\end{array} & \text { MSA } & \text { SMM } & \text { S100 } & \text { Vimentin } & \text { GFAP } & \begin{array}{c}\text { C- } \\ \text { KIT }\end{array} & \text { PLAG1 } & \text { RCC/CD10 } \\ \text { HCCC } & + & + & \text { N/A } & + & + & - & - & - & - & - & - & + & - & \text { N/A } & - \\ \text { MEC } & - & + & + & - & + & - & \text { N/A } & - & - & - & +/- & +/- & +/- & +/- & - & - \\ \text { ACC } & + & + & + & + & - & - & \text { N/A } & - & \text { N/A } & - & + & + & + & +/- & - & - \\ \text { MRCC } & - & \text { N/A } & - & \text { N/A } & - & - & \text { N/A } & - & - & - & \text { N/A } & + & \text { N/A } & \text { N/A } & - & + \\ \text { EMC } & + & + & + & + & + & + & + & + & + & + & + & + & - & - & - & -\end{array}$

CK: cytokeratins, EMA: epithelial membrane antigen, CEA: carcinoembryonic antigen, $\alpha$-SMA: $\alpha$-smooth muscle actin, MSA: muscle-specific actin, SMM: smooth muscle myosin, GFAP: Glial fibrillary acidic protein, PLAG1: Pleomorphic adenoma gene 1, RCC: renal cell carcinoma, PA: pleomorphic adenoma, AdCC: adenoid cystic carcinoma, HCCC: hyalinizing clear cell carcinoma, MEC: mucoepidermoid carcinoma, ACC: acinic cell carcinoma, MRCC: metastatic renal cell carcinoma, EMC: epithelial-myoepithelial carcinoma, +: positive, -: negative, N/A: not available in the literature, +/-: rarely or focal expression $(2,6,9,10,13,17,19,20,24,25)$

\section{Discussion}

Epithelial-myoepithelial carcinoma, a rare malignant disease of salivary gland was first described by Donath et al. in 1972 (5). This tumor mostly develops in parotid gland. Throughout the minor salivary glands, the palate is the most common site involved by the tumor (1). The mean age of patients at diagnosis is 60 years, with a slight female predilection (2). The clinical presentation of this tumor in the parotid gland is usually an asymptomatic, slowgrowing mass which may be present from several years ago, however in minor salivary glands it may exist as an ulcerated mass (6).

Histologically, the tumor consists of varying proportion of two cell types around the duct-like structures. The inner epithelial layer cells were cuboidal to columnar with eosinophilic cytoplasm and the outer layer were myoepithelial cells with clear cytoplasm (1). Table 1 shows the clinicopathologic features and expression of different IHC biomarkers of previously reported cases of EMC in the Englishlanguage literature (2,6-12). The biphasic pattern aforementioned can be seen in some other salivary gland tumors such as benign pleomorphic adenoma, and adenoid cystic carcinoma (AdCC), but these foci are not distributed throughout the tumor (13).

The architectural pattern and relative proportion of the two cell types varies from case to case and within the same lesion (9). As well, the morphologic features of the cells in EMC overlaps with other more common benign or malignant salivary gland tumors. Therefore, this tumor may pose a diagnostic dilemma (14).

The most common tumor of salivary gland is pleomorphic adenoma (15). On microscopic examination, this tumor is composed of epithelial and myoepithelial cells, within variable stroma that may comprise of myxoid, fibrous, chondroid, mucinous, or even osseous tissue. The biphasic pattern of epithelial and myoepithelial cells in this tumor resembles EMC. In epithelial-myoepithelial carcinoma the cellular periphery of the myoepithelial portion is sharp, but in PA it gradually blends into the surrounding stroma named as "melting pattern". In addition, EMC lacks any mucinous or myxochondroid stroma (15).

AdCC is a malignant tumor composed of ductal epithelial and myoepithelial-like cells, resembling EMC in some areas. In AdCC three growth pattern (cribriform, tubular, and solid) can be observed. In addition, the neoplastic cells are basaloid and the myoepithelial cells are less frequently seen than EMC (2).

When the clear cells predominate with a solid growth pattern, both primary and metastatic tumors with clear cells like hyalinizing clear cell carcinoma (HCCC), clear cell variants of mucoepidermoid carcinoma, acinic cell carcinoma (ACC), and, metastatic renal cell carcinoma (MRCC) are encountered in the differential diagnosis (9).

Hyalinizing clear cell carcinoma lacks a biphasic growth pattern and, unlike EMC, HCCC has prominent areas of monomorphic clear cells separated by hyalinized stroma (9). In the incisional biopsies, when sheets of a mixture of clear cells and eosinophilic epithelioid cells are the predominant feature, mucoepidermoid carcinoma is highly considered as the differential diagnosis (probably clear cell type). If EMC is misdiagnosed as MEC, then the pathologist will grade it according to MEC criteria. And Since in EMC the tumor cells are arranged in sheets and exhibit no or little cyst formation and perineural invasion is a common feature in EMC, despite being a low to intermediate grade tumor, EMC would be misdiagnosed as moderate to high grade MEC (16). As well, clear cell variant of MEC has scattered characteristic cells, such as cells with intracytoplasmic mucin, and epidermoid cells (9). In addition, identification of PAS- positive granules in ACC helps to differentiate it from EMC. MRCC lacks biphasic growth pattern and it has more nuclear pleomorphism and atypia (17). As well, the aforementioned tumors lack a myoepithelial cell component (9).

Typically, diagnosis of this tumor is based on conventional hematoxylin-eosin staining and confirmed by immunohistochemistry (4). 
Immunohistochemistry supports the identification of the epithelial and myoepithelial phenotypes (18). On immunohistochemical staining, the epithelial cells reveal expression of epithelial markers, including cytokeratins, epithelial membrane antigen (EMA) $(4,9)$, carcinoembryonic antigen (CEA) (9), and CAM 5.2 (13). By contrast, the myoepithelial cells are negative for epithelial markers and demonstrate immunoexpression of myoepithelial cell markers such as p63, calponin, h-caldesmon, smooth muscle actin, muscle-specific actin, smooth muscle myosin, S100, and vimentin $(18,19)$.

In the present study p63 was applied to highlight abluminal myoepithelial cells as it was suggested as the best myoepithelial marker in these tumor in a series of 61 cases (20). CK7 is considered as a marker of ductal luminal cells which is consistent with epithelial phenotype (21).

IHC findings confirm that the clear abluminal cells are myoepithelial cells and the luminal cells with eosinophilic cytoplasm are originated from duct cells. Some authors suggest that ductal cells are the original cells of the tumor. This is supported by the presence of multiple nodules of hyperplastic intercalated ducts in EMC of parotid (22). In the other hand, Cho et al. reported that the expression of $\mathrm{Ki}-67$ in $\mathrm{EMC}$ is restricted to myoepithelial cells. According to this finding, they suggested a main role for myoepithelial cell in the development of EMC (23). Table 2 demonstrates the use of immunochemistry in differential diagnosis of epithelial-myoepithelial carcinoma $(2,6,9,10,13,17,19,20,24,25)$.

EMC is a low grade malignancy which usually demonstrates low degree of cellular atypia and mitotic activity (9). Until now, there are no definite treatment protocols for these tumors, but surgery is the treatment of choice (9). Surgical excision of the tumor with clear margins provides superior outcomes in terms of recurrence rates and survival (25). In selected cases, the surgery has been followed by adjuvant radiotherapy to avoid local recurrence (18). The efficacy of chemotherapy in the treatment is still unclear (4).

\section{Conclusion}

EMC is a low grade malignant salivary gland tumor which demonstrates biphasic pattern in histopathologic view. This feature could be seen in different salivary gland tumors. Therefore, IHC staining for epithelial and myoepithelial cells can confirm the diagnosis and this will aid in determining the best treatment protocol.

\section{Acknowledgements}

None.

\section{Conflict of Interest}

The authors declared that there is no conflict of interest regarding the publication of this article.

\section{References}

1. Vazquez A, Patel TD, D'Aguillo CM, Abdou RY, Farver W, Baredes S, et al. Epithelial-Myoepithelial Carcinoma of the Salivary Glands: An Analysis of 246 Cases. Otolaryngol Head Neck Surg 2015;153(4):569-74. [DOI:10.1177/0194599815594788] [PMID]

2. Sedassari BT, Dos Santos HT, Mariano FV, da Silva Lascane NA, Altemani A, Sousa S. Carcinoma ex pleomorphic adenoma of minor salivary glands with major epithelial-myoepithelial component: clinicopathologic and immunohistochemical study of 3 cases. Ann Diagn Pathol 2015;19(3):164-8. [DOI:10.1016/i.anndiagpath.2015.03.011] [PMID]

3. McCracken D, Wieboldt J, Sidhu P, McManus K. Endobronchial laser ablation in the management of epithelial-myoepithelial carcinoma of the trachea. Respir Med Case Rep 2015;16:151-3. [DOI:10.1016/j.rmcr.2015.10.003] [PMID] [PMCID]

4. Kim SH, Park SE, Bae HG, Song DH, Oh HH, Cho $\mathrm{KR}$, et al. Epithelial-myoepithelial carcinoma of the nasopharynx: A case report and review of the literature. Oncol Lett 2015;10(2):927-30. [DOI:10.3892/ol.2015.3314] [PMID] [PMCID]

5. Donath K, Seifert G, Schmitz R. [Diagnosis and ultrastructure of the tubular carcinoma of salivary gland ducts. Epithelial-myoepithelial carcinoma of the intercalated ducts]. Virchows Arch A Pathol Pathol Anat 1972;356(1):16-31. [DOI:10.1007/BF00543554] [PMID]

6. Dimitrijevic MV, Tomanovic NR, Jesic SD, Arsovic NA, Mircic AL, Krstic AM. Epithelial-myoepithelial carcinoma--review of clinicopathological and immunohistochemical features. Arch Iran Med 2015;18(4):218-22.

7. Kusama K, Saito M, Kozu M, Shimizu K, Hori M, Tanaka H, et al. Epithelial-myoepithelial carcinoma of the palate. J Oral Pathol Med 1996;25(8):463-6. [DOI:10.1111/j.1600-0714.1996.tb00298.x] [PMID]

8. Li CY, Shirasuna K, Ishibashi H, Nakayama H, Kiyoshima T. Epithelial-myoepithelial carcinoma arising in pleomorphic adenoma of the palate. Oral Surg Oral Med Oral Pathol Oral Radiol Endod 2000;90(4):460-5. [DOI:10.1067/moe.2000.108099] [PMID]

9. Pai RR, Sahu K, Kini AU. Clear cell predominant epithelial-myoepithelial carcinoma of the hard palate - role of immunohistochemistry. Indian J Otolaryngol Head Neck Surg. 2008;60(2):163-5. [DOI:10.1007/s12070-008-0002-4] [PMID] [PMCID]

10. Angiero F, Sozzi D, Seramondi R, Valente MG. Epithelial-Myoepithelial Carcinoma of the Minor Salivary Glands: Immunohistochemical and 
Morphological Features. Anticancer Res 2009;29(11):4703-9. PMID: 20032423

11. Muniz Alves P, Costa da Silva LA, Pina Godoy G, Queiroga de Castro Gomes D, Maria Guedes Queiroz L, Cavalcanti Galvão H. Unusual epithelial-myoepithelial carcinoma in palate- case report and immunohistochemical study. J Clin Exp Dent 2010;2(1):e22-5. [DOI:10.4317/jced.2.e22]

12. Pereira DL, Corrêa MB, Santos-Silva AR, Vargas PA, Lopes MA. Epithelial-myoepithelial carcinoma of the minor salivary glands: a case report and review of the literature. Gen Dent 2016;64(5):304. PMID:27599278

13. Hattori K, Murai N, Kusano J, Takahashi Y. Bilateral epithelial-myoepithelial carcinoma of the parotid glands. Head neck 2016;38(3):E73-5. [DOI:10.1002/hed.24179] [PMID]

14. Molnar SL, Zarka MA, De Las Casas LE. Going beyond "Basaloid neoplasm": Fine needle aspiration cytology of epithelial-myoepithelial carcinoma of the parotid gland. Diagn Cytopathol 2016;44(5):422-5. [DOI:10.1002/dc.23434] [PMID]

15. Kishimoto TE, Yoshimura H, Saito N, Michishita M, Kanno N, Ohkusu-Tsukada K, et al. Salivary Gland Epithelial-Myoepithelial Carcinoma with High-Grade Transformation in a Dog. J Comp Pathol 2015;153(2-3):111-5. [DOI:10.1016/i.jcpa.2015.06.006] [PMID]

16. Luna MA. Salivary mucoepidermoid carcinoma: revisited. Adv Anat Pathol 2006;13(6):293-307.

[DOI:10.1097/01.pap.0000213058.74509.d3] [PMID]

17. Said-Al-Naief N, Klein MJ. Clear cell entities of the head and neck: a selective review of clear cell tumors of the salivary glands. Head Neck Pathol 2008;2(2):111-5. [DOI:10.1007/s12105-008-0052-7] [PMID] [PMCID]

18. Amita K, Vijayshankar S, Abhishek MG, Kumari A. Cytomorphologic Attributes of Epithelial Myoepithelial Carcinoma of Nasal Cavity - A Rare
Tumor with Unusual Clinical Presentation. J Clin Diagn Res 2016;10(9):ED10-ED12.

19. Abdulrahman SS, Mohammad DN, Hamied MA, Abdulqadir MO. Immunohistochemical evaluation of salivary gland tumors differentiation and proliferation by using calponin and telomerase. Saudi Dent J 2019;31(1):105-114. [DOI:10.1016/j.sdentj.2018.11.007] [PMID] [PMCID]

20. Seethala RR, Barnes EL, Hunt JL. Epithelial myoepithelial carcinoma: a review of the clinicopathologic spectrum and immunophenotypic characteristics in 61 tumors of salivary glands and upper aerodigestive tract. Am J Surg Pathol 2007;31(1):44-57.

[DOI: 10.1097/01.pas.0000213314.74423.d8] [PMID]

21. Bansal AK, Bindal R, Kapoor C, Vaidya S, Singh HP. Current concepts in diagnosis of unusual salivary gland tumors. Dent Res J (Isfahan) 2012; 9(Suppl 1): S9-S19.

22. Chetty R. Intercalated duct hyperplasia: possible relationship to epithelial-myoepithelial carcinoma and hybrid tumours of salivary gland. Histopathology 2000;37(3):260-3. [DOI:10.1046/j.1365-2559.2000.00976.x] [PMID]

23. Cho KJ, el-Naggar AK, Ordonez NG, Luna MA, Austin J, Batsakis JG. Epithelial-myoepithelial carcinoma of salivary glands. A clinicopathologic, DNA flow cytometric, and immunohistochemical study of Ki-67 and HER-2/neu oncogene. Am J Clin Pathol 1995;103(4):432-7. [DOI:10.1093/ajcp/103.4.432] [PMID]

24. Zhu S, Schuerch C, Hunt J. Review and updates of immunohistochemistry in selected salivary gland and head and neck tumors. Arch Pathol Lab Med 2015;139(1):55-66. [DOI:10.5858/arpa.2014-0167-RA] [PMID]

25. Goodwin CR, Khattab MH, Sankey EW, Crane GM, McCarthy EF, Sciubba DM. Epithelialmyoepithelial carcinoma metastasis to the thoracic spine. J Clin Neurosci 2016;24:143-6. [DOI:10.1016/j.jocn.2015.07.014] [PMID] 